International Journal of Agriculture and Environmental Research

ISSN: 2455-6939

Volume: 06, Issue: 03 "May-June 2020"

\title{
ARSENIC IN GEOTHERMAL WATERS
}

\author{
1*Abioye, O. FAYIGA and ${ }^{2}$ Uttam, K. SAHA \\ ${ }^{1}$ Stockton University, NJ, USA \\ ${ }^{2}$ The University of Georgia, 2300 College Station Road, Athens, GA 30602, USA \\ *Corresponding author
}

DOI: 10.46609/IJAER.2020.v06i03.007 URL: https://doi.org/10.46609/IJAER.2020.v06i03.007

\section{INTRODUCTION}

Geothermal waters are underground water with a temperature of at least $20{ }^{\circ} \mathrm{C}$ (Wiktorowicz, 2017). Geothermal energy is a form of renewable energy that makes use of heat emanating from geothermal waters to produce electricity and space heating of buildings such as greenhouses, spas and aquaculture (Baird and Cann, 2012). Deep groundwater with a temperature greater than $180{ }^{\circ} \mathrm{C}$ circulating within a geothermal zone and heated by contact with hot rocks is usually found in volcanic regions and island chains (Baird and Cann, 2012). Geothermal systems can either be volcanic or non-volcanic with volcanic based on the emplacement of magma (Meju, 2001). Volcanic geothermal systems include convective hydrothermal systems in hot dry rocks while non-volcanic geothermal systems involves hot fluids in sedimentary rocks flowing through fractures or faults (Meju, 2001). Volcanic rocks can be considered a heat source for geothermal waters (Yildirim and Ozgur, 2017).

In their study of geothermal waters in Turkey, Bello et al. (2017) reported that the rocks were overlain with volcanic rocks and lake sediments of Miocene were deposited. In Russia, the geothermal area is located in the volcanic belt where three groups of thermal manifestations were identified by Chudaev et al. (2017). The three different manifestations were first the fumaroles in the crater itself, secondly, the North Mutnovskaya volcanic zone and thirdly, the volcano's peripheral thermal fields (Chudaev et al., 2017). There is almost a hydrothermal system in every province in China and in southwest China, the geothermal waters are located in the Tengchong volcanic region (Guo et al., 2017). Geothermal waters are not restricted to areas with recent volcanic activities but can also be associated with regional faults that serve as channels for deep penetration of meteoric water in regions with high heat flow related and intensive tectonism (Arango-Galvan et al., 2015). 
International Journal of Agriculture and Environmental Research

ISSN: 2455-6939

Volume: 06, Issue: 03 "May-June 2020"

The local geology is very important in the production of geothermal waters. There are many low to moderate geothermal resources in Turkey which are related to important fracture systems (Bello et al., 2017). The Simay geothermal system in Turkey is believed to be controlled by the active Simay fault which is driven by higher than normal heat flow (Ilkisik, 1995). Bello et al (2017) explained that thermal waters escape into the tectonic zone of weakness, namely the Simay fault, as hot springs to the surface. An investigation of the Muradiye-Caldiran (Van) geothermal field in eastern Turkey revealed that most of the thermal water is discharged along NW-SE trending faults and circulation of thermal water is closely related to major faults and fracture zones (Duzen and Ozler, 2015).

Similarly, well developed faults in the Gonghe geothermal region in China acts as channels for the convective circulation of geothermal waters in the region (Liu et al., 2017). Geothermal waters in Turkey were also related to faults which are generated by compressional tectonic stresses and uplift between two extensional rift zones (Yildirim and Ozgur, 2017). Yilmaz and Ozgur (2017) explained that the geothermal waters ascend in the weakness tectonic zones at the rift zone as hot springs, steams and gases. Giordano et al. (2016) explained that the location of hot springs suggested that hot fluid occurs in areas intensely fractured.

Regardless of location of these geothermal waters, their content of toxic metalloids such as arsenic are a major concern because they may potentially contaminate groundwater which are sources of drinking water to a large population. For example, there is evidence for a mixing process between the fresh groundwater and deep geothermal waters in Babacık Pınarı in western Anatolia, Turkey (Yilmaz and Ozgur, 2017). This mixing process may contaminate fresh groundwater since arsenic concentrations of geothermal waters are about one to three times higher than those of cold groundwaters that are not polluted (Guo et al., 2017).

Exposure to arsenic is a public health concern because the World Health Organization (WHO) has declared arsenic a carcinogen which means cancer causing substance. Exposure to As has been associated with health problems such as cancer, cardiovascular and respiratory diseases, hearing problems, reproductive health problems in pregnant women and it affects the unborn (Fayiga and Saha, 2016).

A severe groundwater As contamination occurred in Bangladesh and west Bengal, India decades ago due to dissolution of arsenic rich minerals in underlying parent rocks (Ravenscroft, 2011). It was observed that symptoms of chronic As toxicity developed after 6 months to 2 years or more of exposure in India and Bangladesh (Rahman et al., 2001). Long-term exposure to As in Bangladesh produced severe arsenicosis which was revealed in skin problems, diabetes mellitus, vascular disease, neuropathy, and also multiple cancers (Ravenscroft, 2011). There was a large percentage of water samples that had high As concentrations above acceptable limits in 
International Journal of Agriculture and Environmental Research

ISSN: 2455-6939

Volume: 06, Issue: 03 "May-June 2020"

Argentina which led to development of skin cancer in patients with arsenicosis while there was a higher incidence rate of colorectal, lung, breast, prostate and skin cancer (Bardach et al., 2015). There are very few papers calling the attention of the public to toxicity of geothermal waters and environmental health effects. The natural sources of As in ground water are dependent on the local geology, hydrology and geochemical characteristics of the aquifers (Bhattacharya et al., 1997). This paper attempts to discuss the genesis of geothermal waters and their hydrochemical characteristics with particular emphasis on arsenic.

\section{Hydrogeochemistry of Geothermal Waters}

Thermal sprigs are main geothermal manifestations and their chemical characteristics often provide information about the origin of geothermal activity (Cruz et al., 2013). Both geochemical reactions and salt precipitation has been reported to influence the heat mining rate from geothermal waters. Cui et al. (2017) reported that the rate of heat mining decreased under the combined influence of geochemical reactions and salt precipitation. Salt precipitation has a higher effect than geochemical reactions on rate of heat mining (Cui et al., 2017). Mineral precipitation and dissolution often accompany the migration of geothermal waters (Zhang et al., 2019). Processes such as boiling, evaporation, concentration and cold-water mixing can occur as hot water from deep thermal reservoirs reach the ground (Zhang et al., 2019).

The hot springs in Indonesia indicated outflow setting with some springs classified as chloridebicarbonate and some others classified as bicarbonate mainly. The chloride-bicarbonate indicate they came from the reservoir while the bicarbonate is either mixed with meteoric water or heated surface water (Fauziyyah et al., 2016). A study in China by Gu et al. (2017) showed how hydrogeochemical characteristics are related to different hydrogeological systems. The main type of water in twelve thermal springs evaluated were bicarbonate-sodium types with temperatures ranging from 22.3 to $41.0^{\circ} \mathrm{C}$ while the mineral springs were bicarbonate-calcium-sodium waters with temperatures between 10.9 to $12.9^{\circ} \mathrm{C}$ (Gu et al., 2017). Isotopic composition showed that the thermal springs were of deep circulating meteoric origin while the mineral waters were from shallow circulating waters.

Similarly, the isotopic composition of thermal waters in Turkey indicate a deeply circulating meteoric origin and geochemical characterization showed the geothermal waters is of the sodium-bicarbonate-chloride type (Gultekin et al., 2019). Hydrogeochemical evaluation of the geothermal field in Turkey showed that the temperature of the thermal waters was $36{ }^{\circ} \mathrm{C}$ while the mineralized spring was about $11^{\circ} \mathrm{C}$ with mean $\mathrm{pH}$ given as 6.83 and electrical conductivity (EC) of $5731 \mu \mathrm{S} / \mathrm{cm}$ (Gultekin et al., 2019). Another study in western Anatolia, Turkey reported geothermal waters classified as sodium-chloride or sodium-chloride-bicarbonate type (Ozgur et al., 2017). 
International Journal of Agriculture and Environmental Research

ISSN: 2455-6939

Volume: 06, Issue: 03 "May-June 2020"

Table 1: Geochemical characteristics of selected geothermal waters

\begin{tabular}{|c|c|c|c|c|c|c|c|c|}
\hline & $\begin{array}{l}\text { Temp } \\
\left({ }^{\circ} \mathrm{C}\right)\end{array}$ & $\mathrm{pH}$ & $\mathrm{EC}(\mu \mathrm{S} / \mathrm{cm})$ & $\begin{array}{l}\mathrm{Mg} \\
(\mathrm{mg} / \mathrm{L})\end{array}$ & \begin{tabular}{|l}
$\mathrm{Na}$ \\
$(\mathrm{mg} / \mathrm{L})$
\end{tabular} & $\begin{array}{l}\mathrm{Cl} \\
(\mathrm{mg} / \mathrm{L})\end{array}$ & $\begin{array}{l}\mathrm{HCO}_{3} \\
\mathrm{mg} / \mathrm{L}\end{array}$ & Reference \\
\hline Indonesia & $35-45$ & $\begin{array}{l}7.0- \\
7.6\end{array}$ & $1710-2890$ & $\begin{array}{l}37.4- \\
227\end{array}$ & $\begin{array}{l}17.4- \\
406\end{array}$ & $8.1-465$ & $\begin{array}{l}427- \\
2100\end{array}$ & $\begin{array}{l}\text { Deon et al. } \\
2015\end{array}$ \\
\hline China & $6-41$ & $\begin{array}{l}6.6- \\
7.8\end{array}$ & 77-909 & $0.1-4.72$ & $4.5-183$ & $0.1-31$ & $44-336$ & $\begin{array}{l}\text { Gu et al. } \\
2017\end{array}$ \\
\hline Turkey & $\begin{array}{l}2.9- \\
39-3\end{array}$ & $\begin{array}{l}6.2- \\
8.5\end{array}$ & 111-6207 & $\begin{array}{l}6.55- \\
65.6\end{array}$ & $\begin{array}{l}11.5- \\
1612\end{array}$ & $\begin{array}{l}0.83- \\
1367\end{array}$ & $\begin{array}{l}155- \\
2691\end{array}$ & $\begin{array}{l}\text { Gultekin et } \\
\text { al } 2019\end{array}$ \\
\hline Russia & $20-39$ & $\begin{array}{l}6.1- \\
6.9\end{array}$ & NA & $\begin{array}{l}17.1- \\
45.0\end{array}$ & $140-358$ & $7.3-33$ & $\begin{array}{l}1232- \\
1910\end{array}$ & $\begin{array}{l}\text { Shestakova } \\
\text { et al., } 2018\end{array}$ \\
\hline UK & $\begin{array}{l}13.5- \\
15.2\end{array}$ & $\begin{array}{l}6.6- \\
7.9\end{array}$ & $\begin{array}{l}1900- \\
40900\end{array}$ & $31-641$ & $\begin{array}{l}215- \\
8550\end{array}$ & $\begin{array}{l}380- \\
11700\end{array}$ & NA & $\begin{array}{l}\text { Burnside } \\
\text { et al., } 2016\end{array}$ \\
\hline Peru & $\begin{array}{l}51.6- \\
91.8\end{array}$ & $\begin{array}{l}6.0- \\
8.0\end{array}$ & $2.7-3.3$ & $5-24$ & $304-658$ & $439-746$ & $93-219$ & $\begin{array}{l}\text { Cruz et al., } \\
2013\end{array}$ \\
\hline Argentina & $\begin{array}{l}30.3- \\
70.2\end{array}$ & $\begin{array}{l}5.8- \\
6.8\end{array}$ & $>6430$ & NA & NA & NA & NA & $\begin{array}{l}\text { Giordano } \\
\text { et al., } 2016\end{array}$ \\
\hline Japan & $\begin{array}{l}40.8- \\
75.7\end{array}$ & $\begin{array}{l}1.4- \\
3.2\end{array}$ & NA & $\begin{array}{l}16.8- \\
64.4\end{array}$ & $\begin{array}{l}29.8- \\
107\end{array}$ & $\begin{array}{l}55.6- \\
127\end{array}$ & NA & $\begin{array}{l}\text { Kikawada } \\
\text { et al., } 2017\end{array}$ \\
\hline Italy & $\begin{array}{l}25.2- \\
76.0\end{array}$ & $\begin{array}{l}6.2- \\
11.6\end{array}$ & NA & $\begin{array}{l}25.0- \\
1290\end{array}$ & $\begin{array}{l}32- \\
11300\end{array}$ & $\begin{array}{l}36- \\
19348\end{array}$ & $\begin{array}{l}168- \\
1098\end{array}$ & $\begin{array}{l}\text { Montanari } \\
\text { et al., } 2017\end{array}$ \\
\hline Morocco & $28-55$ & $\begin{array}{l}5.46- \\
7.41\end{array}$ & $478-15580$ & $\begin{array}{l}16.5- \\
247\end{array}$ & $\begin{array}{l}17.2- \\
2562\end{array}$ & $\begin{array}{l}24.1- \\
4116\end{array}$ & $\begin{array}{l}192- \\
1376\end{array}$ & $\begin{array}{l}\text { Jilali et al., } \\
2018\end{array}$ \\
\hline
\end{tabular}

Thermal waters in Russia range from the high temperature bicarbonate-sodium-calcium type waters to the lower temperature bicarbonate-sodium-calcium type waters indicating a mixing between higher $\mathrm{Na} / \mathrm{Ca}$ geothermal waters and higher $\mathrm{Na} / \mathrm{Ca}$ surface groundwaters (Shestakova et al., 2018). Geochemical characterization of geothermal waters in Peru indicated that the geothermal waters originated by the mixing of meteoric water and magmatic water that was circulating in sedimentary deep rocks (Cruz et al., 2013). The geothermal waters of Peru are of 
the alkaline-chloride-sulphate water type (Cruz et al., 2013). Isotopic data for geothermal waters from Argentina shows a predominantly meteoric origin (Giordano et al., 2016). The high EC, $\mathrm{Mg}, \mathrm{Na}$ and $\mathrm{Cl}$ - in geothermal waters from UK (Table 1) may be due to the mine water geothermal energy production scheme in the area (Burnside et al., 2016).

\section{Arsenic in Geothermal waters}

Due to water scarcity, geothermal waters were supplied to urban communities and used for irrigation and cattle breeding in the Mexican Highlands but the arsenic concentrations measured in the waters range from 0.3 to $3.8 \mathrm{mg} / \mathrm{L}$ (Rodriguez et al., 2015). These concentrations are higher than the maximum contaminant limit of $10 \mu \mathrm{g} / \mathrm{L}$ set by the World Health Organization (WHO).

Table 2: Arsenic concentrations in geothermal waters

\begin{tabular}{|l|l|l|}
\hline Country & As $(\mathrm{mg} / \mathrm{L})$ & Reference \\
\hline Mexico & $0.3-3.8 \mathrm{mg} / \mathrm{L}$ & Rodriguez et al., 2015 \\
\hline Turkey & $680-1150 \mu \mathrm{g} / \mathrm{l}$ & Esetlili et al., 2014 \\
\hline China & $22.1-1150.3 \mu \mathrm{g} \mathrm{L} \mathrm{L}^{-1}$ & Jiang et al., 2018 \\
\hline Taiwan & $0.06-1.46 \mathrm{mg} / \mathrm{L}$ & Maity et al., 2016 \\
\hline Slovakia & $36.7 \mathrm{mg} / \mathrm{L}$ & Vranovská et al., 2015 \\
\hline Iceland & $7-116 \mu \mathrm{g} \mathrm{L}{ }^{-1}$ & Keller et al., 2014 \\
\hline New Zealand & 0.008 to $9.08 \mathrm{mg} \mathrm{l-1}$ & Lord et al., 2012 \\
\hline
\end{tabular}

There were a few cases of keratosis in one of the communities in Mexico where the geothermal water was supplied and some cheese producers reported low concentration of arsenic in their products (Rodriguez et al., 2015). Exposure to low level arsenic $(<50 \mu \mathrm{g} / \mathrm{L})$ in a geothermal area in Italy was associated with skin diseases and circulatory system diseases (Profili et al., 2018). Geothermal features linked to bathing pools are a potential risk to human health if they have high arsenic levels (0.008 to $9.08 \mathrm{mg} \mathrm{l}^{-1}$ ) such as reported in New Zealand (Lord et al., 2012). In such situations, dermal absorption is a potential route of arsenic exposure (Lord et al., 2012).

Masuda (2018) has reported that the distribution of arsenic is strongly related to areas of active plate tectonics, magmatism and associated hydrothermal activity with sources of arsenic contamination identified as mainly hydrothermal water, sulfide and arsenide minerals, volcanic 
International Journal of Agriculture and Environmental Research

ISSN: 2455-6939

Volume: 06, Issue: 03 "May-June 2020"

ash, and iron oxyhydroxide/oxide as weathering products. High concentration of arsenic (10-126 $\mathrm{mg} / \mathrm{L}$ ) on geothermal waters in Tibet was attributed to contribution from the underlying magma chambers (Guo et al., 2019). The magma chambers are likely mantle derived intrusions which are severely contaminated by the deep-seated arsenic-rich sedimentary rocks.

The geological genesis of the magma fluid and its chemical composition is the most critical factor controlling the arsenic concentration of geothermal waters discharging from a magmatic hydrothermal system (Guo et al., 2019). Two sources of arsenic were identified in the volcanic geothermal fluids of Latin America; arsenic partitioned into volcanic gases and emitted in plumes and fumaroles, and arsenic in rocks of volcanic rocks that are leached by groundwaters enriched in volcanic gases (Lopez et al., 2012).

Different species of arsenic such as arsenite, arsenate and thioarsenic species exists in geothermal waters. The main species of arsenic in Daggyai geothermal water in Tibet are arsenite and arsenate though thioarsenic usually exists as the dominant species of arsenic in sulfide-rich thermal springs (Yan et al., 2019). This is based on the fact that a high concentration of sulfide can promote the changing of arsenic into thioarsenic and strong reducing environment is required for the existence of thioarsenic (Yan et al., 2019).

A study has shown that thermophilic microbes such as sulfate reducing bacteria might be involved in the formation of thioarsenates in geothermal systems (Wu et al., 2017). The concentration of arsenic in geothermal waters depends on their genesis and geochemistry, with deep neutral chloride waters usually containing higher As concentrations than shallow acidic sulfate waters (Wang et al., 2018). Geothermal waters in eastern Slovakia are of the sodiumchloride type with arsenic concentrations up to $36.7 \mathrm{mg} / \mathrm{L}$ (Vranovská et al., 2015).

Arsenic in deep geothermal waters can be released to surface waters when there is discharge of hot springs or geothermal wastewater, or via natural mixing of geothermal waters with local shallow groundwaters (Wang et al., 2018). Arsenic is mobilized from deep geothermal systems at low temperatures $\left(150-250{ }^{\circ} \mathrm{C}\right)$ from arsenic bearing pyrite while at high temperature $\left(>250^{\circ} \mathrm{C}\right.$ ), arsenic is mobilized from arsenopyrite (Bundschuh et al.,2016). High arsenic concentrations (Table 2) up to $162,000 \mu \mathrm{g} / \mathrm{L}$ were found in the volcanic geothermal systems of Los Humeros in Mexico (Bundschuh et al.,2016). Arsenic concentrations in geothermal waters from igneous rocks was higher than from sedimentary rocks (Maity et al., 2016). In the Bolivian Altiplano, arsenic concentrations in in cold water samples from shallow aquifers are higher than those in thermal springs (Munoz et al., 2015). 
International Journal of Agriculture and Environmental Research

ISSN: 2455-6939

Volume: 06, Issue: 03 "May-June 2020"

\section{CONCLUSION}

Geothermal energy driven by geothermal waters is a form of renewable energy which is fast gaining acceptance as an alternative to fossil fuel. However, sometimes geothermal water is used for urban water supply or for agricultural purposes in regions with water scarcity. In such situations, the quality of the geothermal water provided to the public is important to protect public health. Several studies have reported high arsenic concentrations above acceptable limits in geothermal waters which could have adverse effects on consumers if used for public water supply. Geothermal waters intended for use as urban water supply should be properly screened for arsenic contamination before use. Geothermal waters with arsenic concentrations higher than allowable limits should not be used for public water supply or for agricultural purposes.

\section{REFERENCES}

Arango-Galvána, C., Prol-Ledesmaa, R., Torres-Verab, M. (2015). Geothermal prospects in the Baja California Peninsula. Geothermics 55, 39-57.

Baird, C., Cann, M. (2012). Environmental chemistry. $5^{\text {th }}$ Ed. W.H. Freeman and Company, New York. pp 350.

Bardach, A.E., Ciapponi, A., Soto, N., Chaparro, M.R., Calderon, M., Briatore, A., et al., (2015). Epidemiology of chronic disease related to arsenic in Argentina: A systematic review, Sci. Total Environ 538: 802-816, http://dx.doi.org/10.1016/j.scitotenv.2015.08.070.

Bhattacharya, P., Chatterjee, D., Jacks, G. (1997). Occurrence of Arsenic-contaminated Groundwater in Alluvial Aquifers from Delta Plains, Eastern India: Options for Safe Drinking Water Supply. Int J Water Resources Develop 1997; 13:79-92, DOI: 10.1080/07900629749944

Bello, O.A., Ozgur, N., Caliskan, T.A. (2017). Hydrogeological, hydrogeochemical and isotope geochemical features of Geothermal waters in Simav and environs, Western Anatolia, Turkey. Procedia Earth and Planetary Science 17, 29 - 32

Bundschuh, J., Herath, I., Vithanage, M. (2016). Natural arsenic and its distribution in global geothermal systems. Arsenic Research and Global Sustainability - Proceedings of the 6th International Congress on Arsenic in the Environment, AS 2016, pp. 29-30.

Burnside, N., Banks, D., Boyce, A., Athresh, A. (2016). Hydrochemistry and stable isotopes as tools for understanding the sustainability of minewater geothermal energy production from a 'standing column' heat pump system: Markham Colliery, Bolsover, Derbyshire, UK. International Journal of Coal Geology 165, 223-230 
International Journal of Agriculture and Environmental Research

ISSN: 2455-6939

Volume: 06, Issue: 03 "May-June 2020"

Chudaev O.V., Chelnokov G.A., Bragin I.V., Kharitonova N.A., Rychagov S.N., Nuzhdaev A.A., Nuzhdaev I.A. (2017). Rare earth and major elements geochemistry of geothermal waters from Mutnovsky volcano, Kamchatka. Procedia Earth and Planetary Science 17, $92-95$.

Cruz, V., Vargas, V., Matsuda, K., Soeda, Y. (2013). Geochemical characterization of the Calacoa geothermal zone. Procedia Earth and Planetary Science 7, 859-862

Cui, G., Zhang, L., Ren, S. (2017). Combined effects of geochemical reactions and salt precipitation on geothermal exploitation in the CPG system. Energy Procedia 105, 1276 $-1281$.

Deon, F., Förster, H., Brehme, M., Wiegand, B., Scheytt, T., Moeck, I., Jaya, M., Putriatni, D. (2015). Geochemical/hydrochemical evaluation of the geothermal potential of the Lamongan volcanic field (Eastern Java, Indonesia). Geotherm Energy (2015) 3:20 DOI $10.1186 / \mathrm{s} 40517-015-0040-6$

Düzen, H., Özler, H. (2015). Investigation of Hydrogeological and Hydrogeochemical Properties of Muradiye-Çaldiran (Van) Geothermal Field, Eastern Turkey. Procedia Earth and Planetary Science 15, $627-634$.

Esetlili, M.T., Colak Esetlili, B., Ozen, F., Bolca, M., Kurucu, Y. (2014). Determination of the arsenic pollution due to geothermal sources in the agricultural lands of Alangullu-Aydin region. Journal of Environmental Protection and Ecology, 15 (4), 1555-1563.

Fauziyyah,,F., Prabowo, T., Shalihin, M., Setiawan, D., Yushantarti, A. (2016). Geochemical Study of Ampallas Geothermal Area, Mamuju District, West Sulawesi Province. IOP Conf. Ser.: Earth Environ. Sci. 42 012002. doi:10.1088/1755-1315/42/1/0120022

Fayiga, A. O., Saha, U. (2016). Arsenic Contamination, Exposure Routes and Public health. Evidence-based Medicine and Public Health, doi: 10.14800/emph.1392.

Giordano, G., Ahumadab, F., Aldegac, L., Baezb, W., Becchiob, R., Bigic, S., Caricchia, C., Chiodib, A., Corradoa, S., De Benedettia, A., Favettod, A., Filipovichb, R., Fusarie, A., Groppellif, G., Invernizzie, C., Maffuccia, R., et al., (2016). Preliminary data on the structure and potential of the Tocomar geothermal field (Puna plateau, Argentina). Energy Procedia 97, 202 - 209.

Gu, X., Zhang, Q., Cui, Y., Shao, J., Xiao, Y., Zhang, P., Liu, J. (2017). Hydrogeochemistry and Genesis Analysis of Thermal and Mineral Springs in Arxan, Northeastern China. Water 2017, 9, 61; doi:10.3390/w9010061 
International Journal of Agriculture and Environmental Research

ISSN: 2455-6939

Volume: 06, Issue: 03 "May-June 2020"

Gültekin, F., Temizel, E., Babacan, A., Kırmac1, M., Arzu Fırat Ersoy, A. Subaşı, B. (2019). Conceptual model of the Şavşat (Artvin/NE Turkey) Geothermal Field developed with hydrogeochemical, isotopic, and geophysical studies. Geotherm Energy 7:12 https://doi.org/10.1186/s40517-019-0128-5

Guo, Q., Liu, M., Li, J., Zhou, C. (2017). Geochemical genesis of arsenic in the geothermal waters from the Rehai hydrothermal system, southwestern China. Procedia Earth and Planetary Science 17, 49 - 52.

Guo, Q., Planer-Friedrich, B., Liu, M., Yan, K., Wu, G. (2019). Magmatic fluid input explaining the geochemical anomaly of very high arsenic in some southern Tibetan geothermal waters. Chemical Geology, 513, 32-43.

Ilkisik, M., (1995). Regional heat flow in Western Anatolia using silica temperature estimates from thermal springs. Tectonophysics 244, 175-184.

Jiang, Z., Li, P., Tu, J., Wei, D., Zhang, R., Wang, Y., Dai, X. (2018). Arsenic in geothermal systems of Tengchong, China: Potential contamination on freshwater resources. International Biodeterioration and Biodegradation, 128, 28-35.

Jilali, A., Chamrar, A., El Haddar, A. (2018). Hydrochemistry and geothermometry of thermal water in northeastern Morocco. Geotherm Energy (2018) 6:9. https://doi.org/10.1186/s40517-018-0095-2

Keller, N.S., Stefánsson, A., Sigfússon, B. (2014). Arsenic speciation in natural sulfidic geothermal waters. Geochimica et Cosmochimica Acta, 142, 15-26.

Kikawada, Y., Ono, T., Ogawa, K., Fukai, M., Oi, T. (2017). Chemical geothermometry studies on a geothermal system in Manza hot springs near Kusatsu-Shirane volcano, Japan. Procedia Earth and Planetary Science 17, 253 - 256.

Liu, M., Guo, Q., Zhang, C., Zhu, M., Li, J. (2017). Sulfur isotope geochemistry indicating the source of dissolved sulfate in Gonghe geothermal waters, Northwestern China. Procedia Earth and Planetary Science 17, $157-160$.

López, D.L., Bundschuh, J., Birkle, P., Armienta, M.A., Cumbal, L., Sracek, O., Cornejo, L., Ormachea, M. (2012). Arsenic in volcanic geothermal fluids of Latin America. Science of the Total Environment, 429, 57-75.

Lord, G., Kim, N., Ward, N.I.(2012). Arsenic speciation of geothermal waters in New Zealand Journal of Environmental Monitoring, 14 (12), 3192-3201. 
International Journal of Agriculture and Environmental Research

ISSN: 2455-6939

Volume: 06, Issue: 03 "May-June 2020"

Maity, J.P., Chen, C.-Y., Bundschuh, J., Bhattacharya, P. (2016). Investigation of arsenic contamination from geothermal water in different geological settings of Taiwan: Hydrogeochemical and microbial signatures. Arsenic Research and Global Sustainability - Proceedings of the 6th International Congress on Arsenic in the Environment, AS 2016, pp. 84-85.

Masuda, H. (2018). Arsenic cycling in the Earth's crust and hydrosphere: interaction between naturally occurring arsenic and human activities. Progress in Earth and Planetary Science, 5 (1), art. no. 68

Meju, M. (2001) Geoelectromagnetic exploration for natural resources: model, case studies and challenges Surv. Geophys. 133-205

Montanari, D., Minissale, A., Doveri, M., Gola, G., Trumpy, E., Santilano, A,, Manzella, A. (2017). Geothermal resources within carbonate reservoirs in western Sicily (Italy): A Review. Earth-Science Reviews 169, 180-201.

Muñoz, O., Bhattacharya, M., Sracek, P., Ramos, O., Aguirre, Q., Bundschuh, J., Maity, J.P. (2015). Arsenic and other trace elements in thermal springs and in cold waters from drinking water wells on the Bolivian Altiplano. Journal of South American Earth Sciences, 60, 10-20.

Özgür, N., Pala, E., Degirmenci, S. (2017). Hydrogeological, Hydrogeochemical and Isotope Geochemical Features of the Geothermal Waters in Seferihisar and Environs, Western Anatolia, Turkey. IOP Conf. Ser.: Earth Environ. Sci. 95022039 doi :10.1088/1755$1315 / 95 / 2 / 022039$

Profili, F., Nuvolone, D., Barbone, F., Aprea, C., Centi, L., Frazzetta, R., Belli, S., Voller, F. (2018). Health effects among a cohort exposed to low-level arsenic in a geothermal area of Tuscany, Italy. International Archives of Occupational and Environmental Health, 91 (8), 971-979.

Rahman, M.M., Chowdhury, U.K., Mukherjee, S.C., Mondal, B.K., Paul, K., Lodh, D., et al. (2001). Chronic arsenic toxicity in Bangladesh and West Bengal, India: A review and commentary. J Toxicol Clin Toxicol 39, 683-700.

Ravenscroft, P. (2011). Arsenic Pollution of Groundwater in Bangladesh, In Encyclopedia of Environmental Health, edited by J.O. Nriagu Elsevier, Burlington, 2011:181-192.

Rodriguez, R., Morales, I., Armienta, A., Villanueva, R., Segovia, N. (2015). Geothermal systems of low temperature in Mexican Highlands: Alternative uses and associated risks. Procedia Environmental Sciences 25, $214-219$ 
Shestakova, A., Guseva, N., Kopylova, Y., Khvaschevskaya, A., Polya, D., Tokarev, I. (2018). Geothermometry and Isotope Geochemistry of CO2-Rich Thermal Waters in Choygan, East Tuva, Russia. Water 10, 729; doi:10.3390/w10060729

Vranovská, A., Bodiš, D., Sracek, O., Ženišová, Z. (2015). Anomalous arsenic concentrations in the Durkov carbonate geothermal structure, eastern Slovakia. Environmental Earth Sciences, 73 (11), 7103-7114.

Wang, Y., Li, P., Guo, Q., Jiang, Z., Liu, M. (2018). Environmental biogeochemistry of high arsenic geothermal fluids. Applied Geochemistry, 97, 81-92.

Wiktorowicz, B. (2017). Hydrogeochemical modelling of forming of geothermal waters in the synclinorium of Łódz. Procedia Earth and Planetary Science 17, 221 - 224.

Wu, G., Huang, L., Jiang, H., Peng, Y., Guo, W., Chen, Z., She, W., Guo, Q., Dong, H.(2017). Thioarsenate formation coupled with anaerobic arsenite oxidation by a sulfate-reducing bacterium isolated from a hot spring. Frontiers in Microbiology, 8, art. no. 1336.

Yan, K., Guo, Q., Liu, M. (2019). Geochemical Anomalies of Arsenic and Its Speciation in Daggyai Geothermal Springs, Tibet. Jilin Daxue Xuebao (Diqiu Kexue Ban)/Journal of Jilin University (Earth Science Edition), 49 (2), 548-558.

Yıldırım, B., Özgür, N. (2017). Hydrogeological, hydrogeochemical and isotope geochemical features of the geothermal waters in Kurşunlu, western Anatolia, Turkey. Procedia Earth and Planetary Science 17, $742-745$.

Zhang, W., Wang,G., Xing, L., Li, T., Zhao, J. (2019). Geochemical response of deep geothermal processes in the Litang region, Western Sichuan. Energy Exploration \& Exploitation, 37(2), 626-645. 